\title{
DIFFERENTIATED ACTIVITIES IN THE CONTEXT OF INCLUSIVE EDUCATION TO ENHANCE THE ACQUISITION OF THE ENGLISH LANGUAGE AT PRIMARY SCHOOL
}

\author{
Evija Latkovska \\ University of Latvia, Latvia \\ Endija Zustrupa \\ Torṇkalna Private Secondary School, Latvia
}

\begin{abstract}
In the $21^{\text {st }}$ century one of the reasons for teachers to pursue continuous professional development is experiencing demanding situations in their lessons, because the concept of mixed-ability teaching has broadened schools being open to diversity. Consequently, different pupils learn together in comprehensive schools and have equal rights to quality education. That also regards language learning. In the present article the authors look upon a situation in which a teacher of English in a comprehensive school has to deal with groups of primary school pupils who have varied needs and preferences for learning a foreign language both academically and socially (for example, having problems with reading and understanding the read material, focusing and keeping attention, working in pairs or groups). Therefore, the use of differentiated activities to enhance primary school pupils' acquisition of the English language is explored. The chosen research method is a case study in which 14 primary school pupils take part. Data collection methods used in the research are observation (a teacher's diary to notice the pupils' strengths and weaknesses of learning English and checklists to gather the evidence of the pupils' learning achievement) and document analysis (test evaluation forms to record the pupils' learning results and progress). The analysis of the gathered data shows that the use of the chosen differentiated activities, which are based on the ideas of mixed-ability teaching and inclusive education, has helped the pupils improve the acquisition of the English language The results of the case study allow the authors to conclude that the varied needs and preferences pupils have for learning a foreign language are a compelling reason for teachers to find new ways of teaching to be able to help each learner prosper.
\end{abstract}

Keywords: acquisition of the English language, inclusive education, language teaching and learning, mixed-ability teaching. 


\section{Introduction}

Every pupil has rights to learn the way it is easier for them to perceive and process information, and it is one of teachers' responsibilities to notice pupils' talents and challenges and adjust the teaching/learning process accordingly. That is complicated, however, not impossible if teachers try to involve all kinds of learners in their lessons. In other words, while getting prepared for their daily work, teachers should have all the pupils in mind, those who are lagging behind and those who are gifted as well, because all of them can cause behavioural problems (Reid, 2017; Hallahan, Kauffman, 2009). The essence of mixed-ability teaching is careful preparation, meticulous selection of materials and creative planning of activities to help each learner make the most of their learning (Dudley, Osvath, 2016; Kaur, 2010; Figg, Jaipal, 2009; Tomlinson, 2005). In general, all classes appear to be mixed-ability with regard to pupils' knowledge, teachers being obliged to come up with lesson plans presenting differentiated learning activities (Dudley, Osvath, 2016).

However, according to Tomlinson (2005), nowadays, mixed-ability classrooms are not only about academic diversity anymore, they also concern learning difficulties or disorders, emotional, cultural, social and even physical disability issues. That leads to the concept of inclusive education. Even though perception of inclusivity regarding education differs, it mainly means full involvement of all pupils in all aspects of schooling regardless of the presence of individual differences (Loreman, Deppeler, 2010). All in all, inclusive education is one of the most topical education issues in the $21^{\text {st }}$ century (United Nations, 2019; Rozenfelde, 2016; Nimante, 2008). The new century has highlighted the necessity for all stakeholders to be united to ensure education is available to as many children of the world as possible not leaving anybody behind. The model of inclusive education envisages that special schools, classrooms for those who are considered to be different are eliminated in order to meet the needs of all pupils under equal conditions (United Nations Educational, Scientific and Cultural Organization [UNESCO], 2013; Westwood, 2011; Loreman, Deppeler, 2010). To optimise the learning process of each pupil, parents should choose the school that corresponds to their pupils' interests and abilities (Buksa, 2016) and in which there is a coordinated support system provided by a team of professionals on a level of the state government, local government and educational establishment if a need should arise. What is more, in this team there should be pupils' parents and teachers, who are understanding, ready to learn and share the gained experience, who are open to the dialogue and cooperation with colleagues as they are the main actors putting ideas of inclusive education into practice (Rozenfelde, 2016). 
Overall, it may be stated that the ideas of mixed-ability teaching are similar to those of inclusive education. Firstly, the similarity lies in the fact that both of them emphasise the importance of making learning more accessible to all pupils despite their varied needs and preferences for learning and the aim of both of them is to cater for each learner's needs. Secondly, another common thing is the role of teachers - in mixed-ability teaching, as well as in inclusive education teachers are of crucial importance as they are the ones who communicate with pupils directly and they are the ones who are responsible for involving pupils in the daily teaching/ learning process. Teachers should be ready for situations in which pupils in their lessons may differ based on the learning style, ability, gender, culture, sexual orientation, socio-economic context, religion, or any other area that may leave impact on a pupil's learning and/or development.

Therefore, the present article gives an insight into the teaching/learning process of English at primary school, where the pupils have different learning needs and preferences, this being the reason for the teacher to apply differentiated activities based on the theoretical underpinnings of mixed-ability teaching and inclusive education. To sum up, the aim of the research is to find out whether primary school pupils having varied needs and preferences for learning a foreign language can be helped to enhance the acquisition of the English language if differentiated activities are used in the language teaching/learning process.

\section{Methods and Materials}

Appropriate to a small-scale education research, the chosen method of research was a case study (Hamilton, 2018; Cropley, 2002), in which 14 seven to nine year old primary school pupils took part (eight Year1 and six Year2 pupils). The research sample was a non-probability convenience sample, which was appropriate for research in education (Cohen, Manion, 2007). One of the researchers was also a participant of the case study being a teacher of English for the pupils of the research sample. The case study lasted for two months - October and November of 2019. Data collection methods used in the research were observation and document analysis:

- observation in a form of a teacher's diary during the first week of the study to notice pupils' strengths and weaknesses to make a list of the most common pupils' needs and preferences for learning English to base the further research on;

- observation checklists with a set of pupils' needs and preferences for learning English after the first week of the study to gather the evidence of the pupils' learning achievement at the beginning and at the end of the study; 
- document analysis - test evaluation forms to record the pupils' learning results and progress at the beginning and at the end of the research.

The analysis of the data gained from the teacher's diary during the first week of observation in October allowed the researchers to notice the pupils' strengths and weaknesses of learning English. The reasons causing trouble for the pupils in the acquisition of the English language were varied, including academic and social issues. The most common pupils' issues were compiled in an observation checklist as affirmative statements for further observation. All in all, the checklist of the observation criteria consisted of 13 items:

- can follow classroom routines;

- can follow internal rules of the school;

- can follow simple instructions in English;

- respects others in the class;

- respects others who are different;

- displays positive attitude towards the English language;

- is willing to use English in class and learns how to do it;

- can use appropriate language items for social relationship;

- can cooperate with others in pairwork, groupwork;

- enjoys different games (without option of competing);

- is able to match the learnt vocabulary items with pictures;

- is able to construct short sentences about the topic;

- is able to ask and answer simple questions about the topic.

Using the observation checklist, every pupil's work was examined for four times (each time two English lessons in a row) in October considering the reoccurrence of the observation criteria in the pupils' work. The criteria were observed in four categories - never, rarely, often, always - based on frequency of the pupils' performance. At this point, there was also a test in English to record the pupils' learning results. According to the requirements of the education system in Latvia, pupils' learning results of English in Year 1 and 2 are evaluated at three levels: still to learn (represented by the symbol '-'); partially mastered (represented by the sign '/') and mastered (represented by the symbol '+').

The profound analysis of the data from the observation checklists and the test evaluation forms was the basis for the researchers to come up with changes to be introduced to the teaching/learning process. According to the pupils' particular needs and preferences for learning English and their test results, a list of differentiated activities was made, considering the theoretical underpinnings of mixed-ability teaching and inclusive education. The list was as follows:

- individual plans (the adjustments slightly differ from pupil to pupil); 
- an opportunity to talk about pupils' feelings and behaviour;

- extended time to complete tasks when necessary;

- making the syllabus real (the topics relevant to pupils' life);

- a multisensory approach (the use of visual, auditory and kinaesthetictactile materials);

- giving simple and clear instructions;

- a strategic seating arrangement in the classroom (an appropriate place for each pupil to feel better and have less contact with irritants);

- the use of graphic organisers and pointers;

- the use of response cards and choral responding (hand and body movements also used as a response);

- project work;

- pairwork, groupwork;

- the use of technology and media;

- physical activity pauses (organised according to each pupil's needs);

- a system of praise and motivation (to point to success rather than failures, providing stickers) (Harris, 2019; Reid, 2017; Buksa, 2016; Dudley, Osvath, 2016; Westwood, 2011; Kaur, 2010; Figg, Jaipal, 2009; Hallanah, Kauffman, 2009; Tomlinson, 2005).

The above-mentioned techniques were used in the lessons of English for four times (each time two English lessons in a row) in November. Lesson plans were similar in both classes, just for pupils of Year 2 being a bit more challenging and advanced. The topic of the month for all the subjects at school, that had to be also applied in English, was Clothes and Colours. Since in each class there was a small group of learners, some of the teaching/ learning process changes could be introduced not only to the whole class teaching, but also used individually for pupils who specifically needed it. Similarly to the observation carried out in October, the pupils' work was examined in November. In total, there were 112 observation checklists at the end of the research. To follow the pupils' academic performance, there was a test at the end of November as well, and its results then were compared to October test results.

\section{Results and Discussion}

With observation as a data collection method it was possible to follow the pupils' learning achievement. The observation criteria are marked in bold further in the text.

As regards the pupils' ability to follow classroom routines and internal rules of the school, it was observed that one month was not enough for the pupils to get used to the new routine and change the attitude towards 
the internal rules at school. However, the pupils' ability to follow simple instructions in English during lessons improved significantly. At the end of the case study there were no pupils who could never comply with simple instructions in English. All in all, eight learners out of 14 moved forward for one position (four pupils moved from never to rarely, two pupils - from rarely to often and two pupils - from often to always).

Respect towards each other and respect towards those who are different being in a small society like a private school is highly important no matter how different everybody is, and even more important is the fact that everyone feels respected in the group/class. Before implementing the differentiated activities, it was observed that two pupils never or rarely showed respect to others in the group, and six pupils never or rarely respected those who were different by making their days in school hard, no one liked to be called names, scolded or ridiculed for being who one was. At the end of the case study all 14 pupils showed respect to their peers in the group either often or always. There were no pupils who would never respect others who were different, two pupils could still rarely respect diversity, seven fell into the category often, but five pupils would always respect classmates who were different. The results proved that the applied differentiated activities had helped the pupils to understand that respecting others and being respected were important.

One of the goals of learning a language is to give learners a chance to socialise and be ready to use the language to communicate in a variety of contexts. Before the use of differentiated activities nine pupils could never or rarely use appropriate language for social relationship according to the acquired knowledge, however, at the end of the case study nine pupils were able to use English in simple communication situations falling into categories often or always. Unfortunately, five pupils remained in the category rarely. The reason for that could be, for example, the fact that pupils, to whom communication was a real challenge, needed more time to improve the communication skill. What was important, it did not mean the particular pupils did not know how to use the language.

The way pupils learn from their teachers, they also learn from other pupils, pupil-pupil interaction may be a great help enhancing knowledge of English. Before applying the differentiated activities five pupils could never or rarely cooperate with others in pairwork, the reason for that possibly being a lack of social skills. At the end of the case study only one pupil could cooperate rarely, four pupils could often cooperate, and nine had no problems to always cooperate with others in pair or groupwork. The pupils' learning achievement was visible. Hence it can be concluded that with the help of appropriate differentiated activities and more practice, pupils can improve their cooperative skills. 
Learning as such at the level of pre-school and primary school to a large extent is organised around playing educational games. However, a problem for pupils having specific needs and preferences for learning is that they are not capable of competing in games. Therefore, for that kind of pupils to enjoy the games an element of competing is not acceptable. At the beginning of the case study, one pupil never enjoyed playing games and refused to participate and six pupils rarely enjoyed games and their first reaction to the idea of playing a game was negative. The other half of the pupils were ready to play games. What the pupils' behaviour showed at the end of the case study was readiness to participate in language games (without competition) - 3 pupils often and 11 pupils always enjoyed playing games.

As regards the pupils' attitude towards the English language and their willingness to use English during the lessons, the analysis of the results showed that the use of the differentiated activities had improved the pupils' achievement in both criteria. While at the beginning of the case study six pupils never or rarely expressed positive attitude towards English, at the end of the case study only two pupils remained in the category rarely, but other 12 pupils were located in the categories often and always. Consequently, if the pupils feel positive about English, they might also be willing to use new skills in the class. Before the application of the differentiated activities two pupils were never and four pupils were rarely willing to use English in class. However, at the end of the case study 13 pupils expressed their will to use and learn English being either in the category often or always, which allowed the authors of the article to conclude that the differentiated activities relevant to the pupils' needs might enhance their motivation to learn and confidence to apply the learnt material thus enhancing their learning achievement in general.

Taking into consideration the pupils' limited knowledge of English and existing challenges with learning, the learning outcomes to be demonstrated by them were rather simple in order to be achievable. Moreover, they were communicative competence oriented which included knowledge of active vocabulary and its use in short sentences being able to ask and answer simple questions about the current topic. At the beginning of the case study four pupils could never and six could rarely complete the necessary language tasks and only two pupils could often and two pupils could always complete the tasks. However, at the end of the case study the results had improved, for example, nine pupils could often and three were always able to match the learnt vocabulary with its pictures, eight pupils could construct short sentences either often or always, but six pupils could often and three pupils could always participate in conversations asking and answering simple questions. The analysis of the results showed that the use 
of the differentiated activities had helped the pupils achieve learning outcomes successfully and demonstrate progress in their learning.

At the end of October and at the end of November there was a test lesson, in which pupils had an opportunity to show the mastered English language competence. As there was such a lesson twice, it was possible to compare the pupils' learning achievement and follow progress that could be witnessed because of the use of the differentiated activities in the lessons of English in November. The results of the present research showed that seven out of 14 pupils had improved their learning results moving one level up. Namely, three pupils had moved from still to learn to partially mastered and four pupils - from partially mastered to mastered. It was gratifying to discover that one pupil had moved even two levels up - from still to learn to mastered, which was a significant achievement. Five pupils had good results both at the end of October and November, while one pupil, unfortunately, did not manage to change the result and it stayed partially mastered. Evaluating work and learning outcomes of pupils who have specific needs and preferences for learning is a complicated process and it differs from evaluating work and learning outcomes of pupils who do not have any specific needs and preferences learning. There might be differences regarding the learning process, quality and quantity of knowledge and skills. Teachers should be careful observing the learning process of pupils having specific needs and preferences for learning as it is not always possible to record pupils' progress according to the compulsory requirements, but it can still be witnessed that pupils have improved their results.

All in all, the pupils' learning achievement and learning results described previously serve as evidence that the applied differentiated activities, which were based on the theoretical underpinnings of mixed-ability teaching and inclusive education, did help primary school pupils having varied needs and preferences for learning a foreign language enhance the acquisition of the English language. Therefore, it is of importance that teachers are ready to adapt to particular circumstances in their daily practice and are motivated to develop professionally.

\section{Conclusions}

One of the preconditions of education in the $21^{\text {st }}$ century is its accessibility to all learners not leaving anyone aside. Moreover, it has to be of high quality notwithstanding any differences learners may display. Mixed-ability teaching in its simplest form caters for all learners mainly regarding their academic achievements. However, inclusive education has broadened the spectrum of those learners' issues which have to be considered by teachers in the teaching/learning process including social, emotional, 
cultural and other matters as well. Even though nowadays besides teachers there are also other stakeholders representing state, local government and educational institutions who are involved in the process of providing equal opportunities for schooling to everyone, a teacher is still the first person who can start to apply appropriate methodologies to help all pupils study and do it successfully. If teachers are open to diversity and ready to work with different pupils in their classrooms using differentiated activities, all the pupils may get a chance to strive for excellence at their own level.

The above-mentioned conclusions made based on the analysis of the theoretical, scientific and methodological literature have been confirmed by the results of the case study too. First of all, mixed-ability teaching in its broader sense is a reality in the $21^{\text {st }}$ century classroom, because pupils do differ not only based on their academic achievements, but also because of their varied needs and preferences for learning. There are primary school pupils who find it complicated to understand English and use it in communication, there are pupils who find it challenging to communicate and work with their peers, and there are also pupils who have not learnt to respect others. Secondly, if a teacher tries to look for specific differentiated activities for particular primary school pupils and for whole class teaching considering the varied needs and preferences for learning a foreign language the pupils have, it is possible that the pupils both enhance their learning of English and improve their social skills. However, it should be noted that the present research was carried out with small groups of learners and the teacher had a chance to observe the work of all the pupils closely and provide particular differentiated activities to each pupil and whole class whenever it was appropriate. Moreover, there was a set time frame - two months - for the research due to the practicalities of the teaching/learning process. Therefore, further investigation of the input of the differentiated activities in the improvement of the acquisition of the English language of primary school pupils having varied needs and preferences for learning a foreign language is necessary.

\section{References}

Buksa, F. (2016). Uzveikt disleksiju. Zvaigzne ABC.

Cohen, L., Manion, L. \& Morrison, K. (2007). Research Methods in Education. Routledge Taylor\&Francis Group.

Cropley, A. (2002). Qualitative research methods. Zinātne.

Dudley, E. \& Osvath, E. (2006). Mixed-Ability Teaching. Into the Classroom. Oxford University Press.

Figg, C. \& Jaipal, K. (2009). Engaging $21^{\text {st }}$ Century Learners and Differentiating Instruction with Technology. Teaching and Learning, 5(1). Downloaded from https:// www.researchgate.net/publication/318749951. 
Hallahan, D. P., Kauffman, J. M. \& Pullen, P. C. (2009). Exceptional Learners (11 ${ }^{\text {th }}$ ed.). Allyn and Bacon.

Hamilton, L. (2018). An Annotated Account of Case Study in Education Research. OUP. Downloaded from http://www.oxfordbibliographies.com/view/document/obo9780199756810/obo-9780199756810-0201.xml.

Harris, B. (2019). Battling Boredom, Part 1: 99 Strategies to Spark Student Engagement. Routledge.

Kaur, H. (2010). Mixed Ability Teaching. VSRD-TNTJ, 1(1). Downloaded from: https:// www.researchgate.net/publication/319617963.

Loreman, T., Deppeler, J. \& Harvey, D. (2010). Inclusive Education: Supporting diversity in the classroom. Routledge.

Nīmante, D. (2008). Bērnu ar speciālām un ịašām vajadzībām ieklaujošā izglitîba Latvijā: vēsturiskais un mūsdienu konteksts. Sociālā pedagoğija. Promocijas darbs pedagoğijas doktora zinātniskā grāda iegūšanai. Latvijas Universitāte. Downloaded from https:// dspace.lu.lv/dspace/bitstream/handle/7/4759/27873-Dita_Nimante_2008._pdf. pdf? sequence $=1$.

Reid, G. (2017). Disleksija agrīnā vecumā, praktiskā rokasgrāmata. Jumava.

Rozenfelde, M. (2016). Skolēnu ar speciālajām vajadzībām iekḷaušanas vispārējās izglìtības iestādēs atbalsta sistēma. Promocijas darbs doktora zinātniskā grāda iegūšanai pedagoǵijā, apakšnozare: nozaru pedagoǵija (speciālā pedagoǵija). Latvijas Universitāte. Downloaded from 298-55964-Rozenfelde_Marite_mr16007.pdf.

Tomlinson, C. A. (2005) How to Differentiate Instruction in Mixed-Ability Classrooms. $2^{\text {nd }}$ edition. Pearson Merrill Prentice Hall.

United Nations. (2019) Report of the Secretary-General on SDG Progress 2019. Special Edition. Downloaded from https://sustainabledevelopment.un.org/content/ documents/24978Report_of_the_SG_on_SDG_Progress_2019.pdf.

United Nations Educational, Scientific and Cultural organization. (2013, June). Inclusive education. Education Sector Technical Notes. Downloaded from https:// unesdoc. unesco.org/ark:/48223/pf0000222124? posInSet $=1 \&$ queryId $=316 \mathrm{c} 5 \mathrm{e}$ 5b-5af2-42c6-8ca8-bc928e2893e1.

Westwood, P. (2011). Common Sense Methods for Children with Special Educational Needs ( $6^{\text {th }}$ ed.). Routledge. 